\title{
Managing Genetic Resources in Temperate Fruit Crops
}

\author{
Shaziya Hassan ${ }^{1}$, K.M. Bhat ${ }^{1}$, Aarifa Jan ${ }^{1}$, Sheikh Mehraj ${ }^{1 *}$, Sartaj Ahmad Wani², \\ Mehraj Ud Din Khanday ${ }^{2}$ and I.A.Bisati ${ }^{1}$
}

${ }^{1}$ Division of Fruit Science, Sher-e-Kashmir University of Agricultural Sciences and Technology-Shalimar, Srinagar, Kashmir, India ${ }^{2}$ Division of Soil Science, Sher-e-Kashmir University of Agricultural Sciences and Technology-Shalimar, Srinagar, Kashmir, India

*Corresponding author: sheikhmehraj10@gmail.com

\begin{abstract}
Biodiversity representing variation within genetic resources at gene, population, species and ecosystem level is our heritage that makes a key contribution to well-being and sustainable development. India is one of the mega biodiversity-rich countries of the world, with only $2.4 \%$ of the land area; it accounts for $7.8 \%$ of all the recorded species on this planet and ranks $10^{\text {th }}$ in the world and $4^{\text {th }}$ in Asia in plant diversity. This richness of species and genetic diversity provides many opportunities, which can be achieved through appropriate management of this diversity. There has been a significant progress in introduction, collection, characterization, conservation and utilization of genetic resources of horticultural crops. Germplasm management activities on temperate fruit in India are primarily carried out by NBPGR, however conservation in field gene banks is also done by various institutes. Besides field gene banks, germplasm of temperate fruits is also conserved by cryobanks, in vitro tissue culture. Thus, in the situation of climate change and depletion of natural resources, the challenges are more to feed growing population, so efforts are required for exploring the unexplored areas for collection of horticultural biodiversity for conservation and utilization for the benefit of mankind. In the quest to meet the emerging challenges, the gains with respect to genetic resources have to be sustained and further collection of new genes are required to be looked and utilized for gains where the strong base of horticultural plant biodiversity have to be in driving seat for bringing gene revolution.
\end{abstract}

Keywords: Germplasm, horticultural crops, cryobanks, NBPGR, ecosystem

The plant genetic resources constitute a reservoir of gene and gene complex and are the raw materials for improvement of horticultural crops (Singh, 2010). Plant genetic resources in horticultural crops and their wild relatives are of immense value to mankind as they provide food, fodder, fuel, shelter and industrial products. The plant breeders require reservoir of genetic variation (gene pools) for crop improvement. The larger the reservoir of variation, the better are the chances of finding particular characters, such as resistance genes for diseases, pests and nematodes or for adaptation to wider ecological amplitudes and stress conditions (Chandel and Pandey, 1991). Genetic resources constitute the foundation upon which horticulture is based.

\section{Kinds of genetic resources}

1. Landraces: These are the primitive or traditional cultivars which are the product of selection carried out by farmers continuously over many generations. They have high level of genetic diversity which provides high degree of resistance to biotic and abiotic stresses.

2. Obsolete cultivars: Improved varieties of recent past are known as obsolete cultivars. These varieties which were popular earlier and now have been replaced by new varieties.

3. Modern cultivars: Presently cultivated high yielding varieties are known modern cultivars. These varieties have high yield potential and uniformity as compared to obsolete varieties and land races. 
4. Advanced breeding lines: Pre-released plants which have been developed by plant breeders for use in modern scientific plant breeding are known as advanced breeding lines.

5. Wild-forms: These are important source of resistance to biotic and abiotic stresses. These can cross easily with cultivated species.

\section{Gene pool}

It refers to whole library of different alleles of a species or sum total of genes. It includes all cultivars, wild species and wild relatives containing all the genes for breeding use.

\section{Classification of Gene pool}

1. Primary gene pool (GP1): Here crossing is easy and leads to production of fertile hybrids. It includes plants that belong to same species or closely related species.

2. Secondary gene pool (GP2): Consists of all biological species that can be crossed with a crop but where the hybrids are sterile, gene transfer is difficult but not impossible.

3. Tertiary gene pool (GP3): Consists of distantly related species and gene transfer is possible with advance techniques.

\section{Biodiversity}

Biodiversity refers to the variation in life in all forms. Crop diversity refers to the variety of genes and genotypes found in a particular crop species. This diversity may occur within species, genera or ecosystem. Biodiversity as our heritage makes a key contribution to well-being and sustainable development.

\section{Biodiversity status of world}

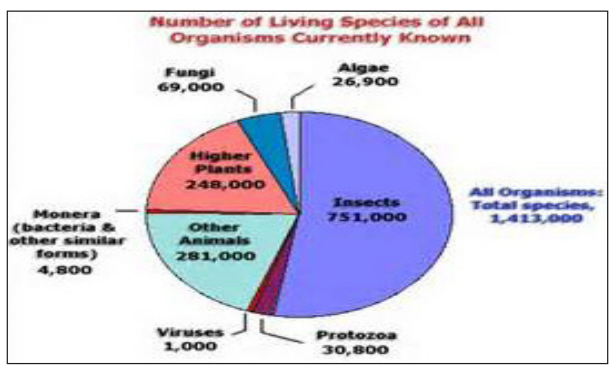

In world higher plants constitute 2, 48,000 species (http:// www. wikipedia.com).

\section{Biodiversity hotspots}

Earth's biological richest places, with high number of species found nowhere else. These represent highest diversity of crop plants. There are presently 34 biodiversity hotspots in world out of which two namely Himalayas and Western Ghats are located in India. (http://www.conservation.org)

\section{Centre of diversity}

It refers to the area where the crop plants show maximum diversity. Centre of diversity is classified into two types viz., primary centre of diversity and secondary centre of diversity.

1. Primary centre of diversity: It refers to the geographical area where crop plants have originated. Such diversity has maximum number of dominant genes and normally wild traits.

2. Secondary centre of diversity: It refers to area where the crop plants show considerable diversity but they were not originated there.

Vavilov in 1951 gave 8 centres of origin which are given below in table:

Table 1: Vavilov's Centre of Origin

\begin{tabular}{|c|c|}
\hline $\begin{array}{l}\text { 1. The Chinese } \\
\text { Centre }\end{array}$ & $\begin{array}{l}\text { Peach, Apricot, Cherry, litchi, } \\
\text { kiwi, plum, loquat, sweet orange, } \\
\text { persimon }\end{array}$ \\
\hline $\begin{array}{l}\text { 2. The Hindustan } \\
\text { Centre }\end{array}$ & $\begin{array}{l}\text { Mango, orange, tangerine, coconut, } \\
\text { tamrind, banana, phalsa, jackfruit }\end{array}$ \\
\hline $\begin{array}{l}\text { 3. The Central Asiatic } \\
\text { centre }\end{array}$ & $\begin{array}{l}\text { Pear, Apple, Pistachio, Almond, } \\
\text { grape, walnut }\end{array}$ \\
\hline $\begin{array}{l}\text { 4. The Asia Minor } \\
\text { Centre }\end{array}$ & $\begin{array}{l}\text { Apricot, pistachionut, almond, } \\
\text { pomegranate, quince, date palm }\end{array}$ \\
\hline $\begin{array}{l}\text { 5. The Mediterranean } \\
\text { Centre }\end{array}$ & Olive \\
\hline 6. Abyssinian Centre & Coffee \\
\hline $\begin{array}{l}\text { 7. The central } \\
\text { American Centre }\end{array}$ & Cocoa, papaya, guava \\
\hline $\begin{array}{l}\text { 8. The South } \\
\text { American Centre }\end{array}$ & Pineapple, cashew \\
\hline
\end{tabular}

\section{Scenario of plant biodiversity in India}

India is one of the mega biodiversity-rich countries of the world. With only $2.4 \%$ of the land area, it accounts for $7.8 \%$ of all the recorded species on this planet. It ranks $10^{\text {th }}$ in the world and $4^{\text {th }}$ in Asia in plant diversity. India is home to 167 important cultivated crop species and 320 species of their wild relatives (Rana, 2012). 


\section{Why to manage biodiversity}

Management of biodiversity is very important because recently biodiversity is declining at an alarming rate which is a concern for all people in the world. The reasons for why we need to manage biodiversity are discussed below:

1. Genetic erosion: Genetic erosion is the gradual change in genetic variability, in the population of a species, due to elimination of various genotypes. In other words, the loss of genetic diversity caused by either natural or man-made processes is referred to as genetic erosion. It includes loss of individual genes, and the loss of particular combination of genes such as those manifested in locally adapted landraces of domesticated plants adapted to the natural environment in which they originated. It is caused due to replacement of land races by modern cultivar, industrial agriculture, farming into wild habitat, clean cultivation and developmental activities.

2. Climate change: Climate change is the long term shift in the statistics of weather. It has a huge impact on biodiversity loss. It has resulted in the loss of valuable sources of genes. In some fruit-growing regions such as the Central Valley of California, the percent of the landscape suitable to apple production has decreased from 50 percent in 1950, to less than 4 percent today, and will likely be entirely lost by 2050. A reduction in chill hours will soon force a shift in varieties if fruit production is to continue at all. Although it is certainly possible to breed for low-chill tolerant fruits, chilling hours are not the only factors affected by global climate change. The spread of newly-introduced diseases and pests, the increasing frequency of tropical storms and devastating droughts, are already affecting the conservation and production of diverse fruits. Screening the diversity of extant fruit varieties for low-chill requirements, drought and salinity tolerance and pest or disease resistance may be far more cost effective than breeding alone; both need to be advanced (Nabhan, 2010).
3. Continuous destruction of habitat and extinction of wild relatives: Humans have a great role in maintaining nature. Either they save it or destroy it with their activities. Human pressure threatens many species and ecosystems, so conservation efforts necessarily prioritize saving them. Due to increasing population and urbanization across the globe humans are now destroying the natural habitats for many purposes like constructions and other developmental works which have resulted in extinction of many wild species and thus ultimately resulting in the loss of valuable genes.

4. Improvement programmes: Genetic variability is very important for the improvement of crops because improvement through breeding in a crop is possible only when there is considerable diversity for that crop. From the above discussed reasons it is thus very important that the germplasm have to be managed.

Management of germplasm: It involves following steps:

1. Germplasm introduction

2. Germplasm collection

3. Germplasm characterisation

4. Germplasm conservation

5. Germplasm evaluation

6. Germplasm utilization

\section{Germplasm introduction}

Introduction refers to the transposition of crops from their area of cultivation to the area where they have never been grown. Introduced varieties and species have contributed significantly to the improvement of horticulture in India. Introduced crops are either directly used as varieties (primary introduction) or used in breeding for improving quality, productivity and imparting resistance (Secondary introduction). These include more than 5000 accessions of fruit crops. The NBPGR has been instrumental in introducing many new varieties like Red Delicious, Bartlett pear, Elberta peach, Santa Rosa, Loose Perlett, Thompson Seedless, Kinnow, etc. (Singh, 2010). The Fruit science division of Sher-e- Kashmir University of Agricultural Sciences 
and Technology Kashmir have introduced some crop cultivars which are given in Table 2.

Table 2: Apple, pear and cherry varieties introduced by Division of Fruit Science, SKUAST-Kashmir

\begin{tabular}{llll}
\hline Crop & \multicolumn{2}{l}{ Year of introduction } & Rootstocks \\
\cline { 2 - 3 } & $\mathbf{2 0 0 9}$ & $\mathbf{2 0 1 3}$ & \\
\hline Apple & Golden Delicious & Super Chief & M9 \& T337 \\
& Reinders, Granny- & Sandidge, Fuji & \\
& Smith, Gale Gala, & Aztec, Gala & \\
& Red Chief Camspur, & Red Lum, & \\
& & Golden-Clone & \\
& & B, Red Velox & \\
Pear & & Carmen, & Quince C \\
& & Abbate Fetchel & \\
Cherry & & Regina & Giesela- 5 \\
\hline
\end{tabular}

\section{Germplasm exploration/ Collection}

The indigenous germplasm collection includes more than 5000 accessions of fruit crops. Collection of germplasm of fruit crops is very important and should be carried in the areas having high diversity. Germplasm collection is undertaken by NBPGR in India and they have collected germplasm from different parts of country as shown in Table 3.

Table 3: Total explorations undertaken and germplasm collected by NBPGR (Anon., 2013)

\begin{tabular}{lcc}
\hline $\begin{array}{l}\text { Headquarters/ Regional } \\
\text { Stations/ Base Centres }\end{array}$ & $\begin{array}{c}\text { Explorations } \\
\text { Undertaken }\end{array}$ & $\begin{array}{c}\text { Accessions } \\
\text { Collected }\end{array}$ \\
\hline $\begin{array}{l}\text { Jodhpur (Arid region) } \\
\begin{array}{l}\text { Thrissur (Southwest coastal } \\
\text { region) }\end{array}\end{array}$ & 2 & 135 \\
$\begin{array}{l}\text { Cuttack (Humid/ moist tropical } \\
\text { east coastal region) }\end{array}$ & 3 & 174 \\
$\begin{array}{l}\text { Shillong (Northeast Hill region) } \\
\text { Bhowali (Central Himalayan }\end{array}$ & 3 & 185 \\
$\begin{array}{l}\text { region) } \\
\text { Shimla (Northwest Himalaya \& } \\
\text { high altitude region) }\end{array}$ & 4 & 124 \\
$\begin{array}{l}\text { Srinagar (Northwest } \\
\text { Himalaya\&high altitude } \\
\text { region) }\end{array}$ & 2 & 86 \\
$\begin{array}{l}\text { New Delhi (Northwest plains) } \\
\text { Ranchi (Sub-tropical humid } \\
\text { region) }\end{array}$ & 9 & 66 \\
$\begin{array}{l}\text { Akola (Central Indian region) } \\
\text { Hyderabad (Southeast coastal } \\
\text { region) }\end{array}$ & 2 & 111 \\
\hline & 6 & 356 \\
& 2 & \\
\hline
\end{tabular}

There is a large germplasm collection maintained in The Fruit science division of Sher-e-Kashmir University of Agricultural Sciences and TechnologyKashmir have introduces some crop cultivars which are given in table 4 .

Table 4: Germplasm collection at SKUAST- Kashmir, Shalimar campus, Srinagar

\begin{tabular}{|c|c|}
\hline Fruit crop & Collections \\
\hline Apple & $\begin{array}{l}\text { Red Delicious, Gala Mast, Early Red One, } \\
\text { Oregon Spur, Vance Delicious, Starkrimson, } \\
\text { Red Chief, Wells Spur, Silver Spur, Top Red, } \\
\text { Royal Delicious, Chamura, Firdous, Shireen, } \\
\text { Shalimar II, Shalimar I, Golden Delicious, } \\
\text { Akbar, Lal Ambri, American apirouge, } \\
\text { Sunhari }\end{array}$ \\
\hline Pear & William Bartlett, Fertility, Kashmiri Nak \\
\hline Strawberry & $\begin{array}{l}\text { Dilpasand, Blackmore, Red Coat, } \\
\text { Camarosa, Anthena, Katrain Sweet, Larson, } \\
\text { Elasta, Banglora, Missionari, Red Cross, } \\
\text { Henna, Fiana, Majestic, selva, Chandler, } \\
\text { Phenomenon, Ofra, Jutogh Special, Belrubi, } \\
\text { Sweet Charlie, Douglas, Sea Scape, Addie, } \\
\text { Brighton }\end{array}$ \\
\hline Plum & $\begin{array}{l}\text { Santa Rosa, Grand Duke, Vixon, Satsuma, } \\
\text { Burbank, Duret, Friear, Green Guage, New } \\
\text { Plum, Saben Aer }\end{array}$ \\
\hline Nectarine & Silver King, Red Gold, Snow Queen \\
\hline Walnut & $\begin{array}{l}\text { SKAUW-0001, SKAUW-0002, SKAUW-0004, } \\
\text { SKAUW-0005, SKAUW-0040, SKAUW-0006, } \\
\text { SKAUW-0007, SKAUW-0008, SKAUW-0010, } \\
\text { SKAUW-0015, SKAUW-0016, SKAUW-0020, } \\
\text { SKAUW-0022, SKAUW-0023, SKAUW-0024, } \\
\text { SKAUW-0025, SKAUW-0027, SKAUW-0035 } \\
\text { Drajnovesky, Lake English, Chenovo, } \\
\text { Hamdan, Sulaiman, }\end{array}$ \\
\hline Cherry & $\begin{array}{l}\text { Lapins, Stella, Rainier, Regina, Sweet Heart, } \\
\text { Bing, Mishri, Double }\end{array}$ \\
\hline Kiwi & $\begin{array}{l}\text { Abbot, Allison, Hayward, Bruno, Monty, } \\
\text { Toumari }\end{array}$ \\
\hline Apricot & $\begin{array}{l}\text { Amba, Australian Sweet, Charmagz, Quetta, } \\
\text { Kaisha, Halman, Gilgit Sweet }\end{array}$ \\
\hline
\end{tabular}

\section{The Apple Collection in Geneva, NY: A Resource for the Apple Industry Today and for} Generations to Come

The National collection of apples was assembled and is maintained by the Plant Genetic Resources Unit (PGRU) located on the campus of Cornell University's New York State Agricultural Experiment Station. The PGRU is part of a network of germplasm repositories that belong to the 
National Plant Germplasm System (NPGS) of the United States Department of Agriculture (USDA) Agricultural Research Service (ARS). The PGRU is tasked with "Conservation and Utilization of the Genetic Resources of Grapes, Apples, and Tart Cherries." Intotal, 6,883 diverse apple varieties are maintained at the PGRU. This includes 2510 apple clones (1,410 Malus x domestica; 329 Malus hybrids; and 771 clones belonging to 54 Malus species) all maintained in duplicate field plantings at Geneva. Additionally, 1,565 seed lots of wild Malus species including approximately 950 seed lots of Malus sieversii, the main progenitor species of the cultivated apple (M. $x$ domestica) from Central Asia are kept in cold storage at the PGRU with backups at the USDA-ARS National Centre for Genetic Resources Preservation (NCGRP) in Ft. Collins CO. About 2,808 seedlings representing 310 of these $M$. sieversii seed lots are being grown as trees for field evaluation. Of the 6,883 apple varieties, a core collection of 255 clones has been designed to represent the diversity of apple. Furthermore, approximately 2,275 clones are backed up in cryogenic storage (liquid Nitrogen) at the NCGRP and 436 are also in cryogenic storage on-site at PGRU (Fazio et al. 2008). The Central Institute of Temperate Horticulture is the regional station of NBPGR in Jammu and Kashmir and its collections are given in Table 5 .

Table 5: Germplasm collection and conservation at CITH (2003-08)

\begin{tabular}{cccccc}
\hline $\begin{array}{c}\text { S. } \\
\text { No. }\end{array}$ & $\begin{array}{c}\text { Crop/ } \\
\text { group }\end{array}$ & \multicolumn{2}{c}{$\begin{array}{c}\text { Germplasm } \\
\text { status }\end{array}$} & $\begin{array}{c}\text { Total } \\
\text { collections }\end{array}$ & $\begin{array}{c}\text { \% increase } \\
\text { during this } \\
\text { period }\end{array}$ \\
\cline { 3 - 4 } & & $\mathbf{2 0 0 3}$ & $\mathbf{2 0 0 8}$ & & 79 \\
\hline & Fruits & 339 & 267 & 606 & 47 \\
1 & Pome & 163 & 76 & 239 & 51 \\
2 & Stone & 79 & 40 & 119 & 183 \\
3 & Nuts & 60 & 110 & 170 & 111 \\
\hline
\end{tabular}

(http://www.cith.org.in)

\section{Current trends in plant genetic resources}

From Qualitative: It includes collecting, documenting, evaluating individual accessions.

To Quantative: It includes screening with molecular based techniques.

\section{Germplasm characterization}

It refers to the observation, measurement and documentation of heritable plant traits in a collection. It allows for identifying and classifying accessions, building a catalogue of descriptors with biological information essential for collection management and aims at describing and understanding the genetic diversity of the organisms under study. Over the years a large germplasm of diverse horticultural crops has been characterized and evaluated, promising germplasm have been identified and utilized in crop improvement programmes, in the ICAR network. In addition to morpho-agronomic evaluation, several accessions of vegetables, fruits and medicinal aromatic plants have been analyzed for chemical constituents. Some accessions have also been subjected to molecular characterization. However, systematic evaluation of reaction to biotic and abiotic stresses, nutritionally important constituents or processing attributes has not been done adequately.

\section{Molecular characterization of germplasm}

To make the characterisation more effective and to identify the best genotypes molecular markers are now being used for characterization of germplasm. The molecular characterization is achieved through DNA finger printing Technique. DNA finger printing technique in its original sense refers to the method developed in 1985 by Sir Alec Jeffreys (Jeffreys et al. 1985) and his associates for the simultaneous detection of highly variable DNA fragments by hybridization of specific multilocus probes to electrophoretically separated restriction fragments. The DNA fragments, resembling barcodes, are unique to the individual and hence can be used in much the same way as conventional fingerprints- to identify individuals with absolute certainty. Importance of DNA fingerprinting is that it helps to form primary core collection which can be conserved and utilized and helps in removal of duplicates. Zhang et al. (2012) carried evaluation of genetic diversity in Chinese Wild Apple species along with apple cultivars using SSR Markers. In their study, a total of 16 unique alleles were identified in 29 apple accessions using 19 SSR markers. Of these 16 unique alleles, ten $(62.5 \%)$ were exclusively present in Chinese wild apple species. Moreover, the UPGMA Dendrogram indicated that 
the Chinese wild apple species were separated from cultivars. These results clearly suggested that the Chinese wild apple species had wider genetic diversity and would serve as valuable resources for apple breeding efforts.

Table 6: List of Walnut genotypes used for molecular characterisation

\begin{tabular}{cccccc}
\hline S. No. & Genotypes & Code & S. No. & Genotype & Code \\
\hline 1 & SKAUW-0001 & 16 & 15 & SKAUW-0025 & 6 \\
2 & SKAUW-0002 & 19 & 16 & SKAUW-0027 & 26 \\
3 & SKAUW-0004 & 20 & 17 & SKAUW-0035 & 17 \\
4 & SKAUW-0005 & 21 & 18 & SKAUW-0040 & 13 \\
5 & SKAUW-0006 & 22 & 19 & Drajnovesky & 2 \\
6 & SKAUW-0007 & 23 & 20 & Tuttle- 31 & 27 \\
7 & SKAUW-0008 & 11 & 21 & M. C. Kinister & 24 \\
8 & SKAUW-0010 & 14 & 22 & Lake English & 18 \\
9 & SKAUW-0015 & 12 & 23 & Chenovo & 1 \\
10 & SKAUW-0016 & 10 & 24 & K-5 & 25 \\
11 & SKAUW-0020 & 15 & 25 & Hamdan & 7 \\
12 & SKAUW-0022 & 3 & 26 & Sulaiman & 9 \\
13 & SKAUW-0023 & 4 & 27 & Bulbul & 8 \\
14 & SKAUW-0024 & 5 & & & \\
\hline
\end{tabular}

(Wani, 2011).

In this study held at SKUAST-Kashmir no promising genotype was identified because the trees were very young at that time and could not fully exploit their genetic potential.

\section{Germplasm conservation}

Germplasm once lost cannot be replaced so its conservation is very important for sustainable life. Conservation refers to the preservation of germplasm. The conservation of germplasm is achieved by two methods.

1. In-situ conservation

2. Ex-situ conservation

\section{In- situ conservation}

This type of conservation allows the crop species to grow in their natural habitat. In-situ is normally defined by geographical area rather than by species, as in case of natural habitats in protected areas and national reserves. Therefore, both known and unknown species are conserved. As this is done in natural habitats it allows evolutionary processes to continue, which are base of genetic diversity and plant adaptability. It can be carried out in the form of biosphere reserves, habitats, wildlife parks, gene sanctuaries and national parks (Chaudhary, 2000). In world there are 500 biosphere reserves in 100 countries including India. India has 18 biosphere reserves, many national parks and gene sanctuaries (http:// www.wikipedia.com). Highest diversity of fruits in India is in North eastern region followed by Western Peninsular tract and Western Himalayas. First In situ gene sanctuary in India was established for citrus in Tura hill range of Garo hills in Meghalaya (Singh, 2010).

\section{Ex-situ conservation}

In this method conservation of germplasm is carried outside their native habitat in the form of seed, embryo, tissue, etc. Objective of ex-situ conservation is to maintain the accessions without any change in genetic constitution. At present about 7.4 million accessions are stored in ex-situ collections worldwide (FAO, 2010). It involves conservation through:
(a) Seed gene bank
(b) Field gene bank
(c) In-vitro gene bank
(d) Pollen storage
(e) DNA storage

\section{Seed gene bank}

It involves conservation of genetic resources for long-term through seed storage. Seeds with 3-5\% moisture content are stored at $-20^{\circ} \mathrm{C}$. It is mainly used for orthodox seeds e.g., temperate fruits In India more than 300000 accessions have been conserved in seed bank at NBPGR, New Delhi including fruits, vegetables, spices, medicinal and aromatic plants [NBPGR,2011; http://www.nbpgr. ernet.in]. On the basis of temperature regime, the storage is classified into:

(a) Medium term storage for active collections at $0-4^{\circ} \mathrm{C}$ for a time period of $10-15$ years.

(b) Long term storage for base collections at $20^{\circ} \mathrm{C}$ for a period of $50-100$ years.

(c) Storage of seeds at $5-10^{\circ} \mathrm{C}$ for working collection for a period of 3-5 year

(Gupta, 2010). 


\section{Field gene bank}

The field gene bank is an area where the growing plants are conserved. Most of horticultural genetic resources are either difficult or impossible to conserve as seeds because of being recalcitrant or they reproduce vegetatively and hence conserved in field gene banks. Germplasm of major fruits is being maintained in FGBs by horticultural institutes, NRCs, SAUs and NAGS.

Table 7: Crop based national active germplasm sites for HGR

\begin{tabular}{|c|c|c|c|}
\hline Crop & Institute & $\begin{array}{l}\text { Seed } \\
\text { bank }\end{array}$ & $\begin{array}{l}\text { Field } \\
\text { bank }\end{array}$ \\
\hline Arid fruits & $\begin{array}{l}\text { Central institute on Arid } \\
\text { Horticulture, Bikaner }\end{array}$ & 1319 & 1229 \\
\hline Banana, Plantain & $\begin{array}{l}\text { NRC on Banana, } \\
\text { Tiruchirapalli }\end{array}$ & & 907 \\
\hline Cashew & NRC for Cashew, Puttur & & 519 \\
\hline Citrus species & NRC on Citrus, Nagpur & & 150 \\
\hline Grapes & NRC for grapes, Pune & & 600 \\
\hline $\begin{array}{l}\text { Litchi, Bael, Aonla } \\
\text { \& Jackfruit }\end{array}$ & $\begin{array}{l}\text { NRC on Litchi, } \\
\text { Muzaffarpur }\end{array}$ & & 2426 \\
\hline Mango, Guvava & CISH, Lucknow & & 848 \\
\hline Sub-tropical fruits & $\begin{array}{l}\text { AICRP on Sub-tropical } \\
\text { Fruits, CISTH, Luknow }\end{array}$ & & \\
\hline Oil palm & $\begin{array}{l}\text { NRC on Oil palm, } \\
\text { Pedavegi, A.P }\end{array}$ & & 103 \\
\hline Plantation crops & $\begin{array}{l}\text { Central Plantation Crops } \\
\text { Research }\end{array}$ & & 522 \\
\hline $\begin{array}{l}\text { Temperate } \\
\text { Horticultural } \\
\text { crops }\end{array}$ & $\begin{array}{l}\text { CITH, Srinagar and CITH, } \\
\text { NBPGR RS, Shimla }\end{array}$ & & $\begin{array}{l}780 \\
\& 908\end{array}$ \\
\hline Tropical fruits & IIHR, Banglore & 1983 & 1754 \\
\hline Tropical fruits & $\begin{array}{l}\text { AICRP on Tropical Fruits, } \\
\text { Banglore }\end{array}$ & - & \\
\hline
\end{tabular}

(Singh, 2010).

\section{In-vitro gene bank}

It involves conservation of horticultural genetic resources (HGR) using tissue culture techniques. There are several advantages of in vitro techniques such as high multiplication rate, growth of plants under aseptic conditions, requirement of relatively less space, reduce genetic erosion, ready available material for distribution and limited quarantine restriction for exchange of material (Gupta, 2010). Over 37,600 accessions of germplasm conserved worldwide with NBPGR having largest In vitro collection in India (Singh, 2010). Important examples: are Musa species (411), Pyrus species (66), Morus species (61). It is achieved through:
(a) Slow growth
(b) Cryopreservation

\section{Slow growth}

The main aim of this method is to maintain cultures under growth limitation so as to reduce requirement of frequent sub-culturing. Some of the various approaches to achieve slow growth are discussed below:

(i) Low Temperature Incubation: this method is very simple, easy to use and may be applicable to a wide range of genotypes. Here, the in vitro cultures are maintained at low temperature that affects the metabolic activities which in turn restrict the growth of the plant. The storage temperature, generally is crop specific, for example, cold tolerant species like Frageria and Prunus can be stored between $0-4^{\circ} \mathrm{C}$ (Wilkins et al. 1988; Reed, 1992).

(ii) Use of Growth Regulator: Some of the commonly used growth regulators are ABA, phosphon $\mathrm{D}$, maleic hydrazide. These are used to reduce the overall growth of the in vitro plantlets and thereby enhance the subculture intervals (Gupta, 2010).

(iii) Use of Minimal Growth Media and Restrictive Growth Conditions: carbon source has a marked effect on the growth rate. Alteration of optimum dose could reduce the growth rate of cultures in many species.

Table 8: Status of in-vitro conserved germplasm in India (Anon, 2013)

\begin{tabular}{lcccc}
\hline Crop group & $\begin{array}{c}\text { Genera } \\
\text { (no.) }\end{array}$ & $\begin{array}{c}\text { Species } \\
\text { (no.) }\end{array}$ & $\begin{array}{c}\text { (no.) } \\
\text { (noltures }\end{array}$ & $\begin{array}{c}\text { Accessions } \\
\text { (no.) }\end{array}$ \\
\hline $\begin{array}{l}\text { Tropical fruits } \\
\text { (banana }\end{array}$ & 2 & 14 & 10,000 & 416 \\
$\begin{array}{l}\text { Temperate and } \\
\text { Minor Fruits (apple, } \\
\text { apricot, blackberry, } \\
\text { blueberry, pear, } \\
\text { strawberry) }\end{array}$ & 9 & 41 & 6,700 & 317 \\
$\begin{array}{l}\text { Tuber crops (sweet } \\
\text { potato, yam, taro) }\end{array}$ & 5 & 12 & 9,800 & \\
\end{tabular}




\begin{tabular}{lllll}
$\begin{array}{l}\text { Bulbous and other } \\
\text { crops (garlic, } \\
\text { gladiolus) }\end{array}$ & 4 & 12 & 3,300 & 171 \\
$\begin{array}{l}\text { Medicinal and } \\
\text { aromatic plants }\end{array}$ & 21 & 28 & 5,000 & 174 \\
$\begin{array}{l}\text { Species of } \\
\text { Coleus, Rauvolfia, }\end{array}$ & & & & \\
$\begin{array}{l}\text { Tylophora, } \\
\text { Valeriana) }\end{array}$ & & & & \\
$\begin{array}{l}\text { Spices and } \\
\text { industrial crops } \\
\text { (ginger, turmeric, } \\
\text { pepper, cardamom, }\end{array}$ & & 27 & 5,800 & 380 \\
hops, jojoba) & & & & \\
\hline \begin{tabular}{l} 
TOTAL \\
\hline
\end{tabular} & & & & \\
\hline
\end{tabular}

\section{Cryopreservation}

Cryopreservation is a relatively new conservation method and protocols have been developed for conservation of various crops for long term storage at $-196^{\circ} \mathrm{C}$ under liquid nitrogen or vapour phase (Gupta, 2010). Cryopreservation comprises of following steps:

(a) Choice of explant: explant includes shoot apex, somatic embyros, seed, excised zygotic embryo, dormant vegetative bud and pollen

(b) Pre-culture: Culture of cells, tissues, organs in the presence of amino acids like proline, sugars/ sugar alcohols like sucrose and mannitol or at low temperature prior to freezing initiates in them important physiological changes which increase their freezing tolerance. Plantlets may be hardened by growing them at $-1^{\circ} \mathrm{C}$ for 16 hours each day. Rapid dehydration is done by application of sucrose at concentration of 30-240g/l.

(c) Cryoprotectant: Here Cryoprotectant like dimethyl sulphoxide (DMSO), glycerol or sorbitol are given to tolerate cryoinjury.

(d) Cooling: the material is cooled $0.5-4^{\circ} \mathrm{C} / \mathrm{min}$ up to -40 to $-100^{\circ} \mathrm{C}$ for $20-45$ minutes.

(e) Storage in liquid nitrogen: Finally the explant is stored in liquid nitrogen at $-196^{\circ} \mathrm{C}$.

Pollen storage: Involves conservation of germplasm through pollen cryopreservation.

DNA storage: Involves storage of total genomic information in the form of DNA libraries.

\section{Cryopreservation of dormant buds in apple involves}

- Dormant scions from field grown material are cut in $3.5 \mathrm{~cm}$ segments containing a single bud.

- The stem segments are dried to $25-30 \%$ moisture at $-5^{\circ} \mathrm{C}$.

- The dried segments are packed into cryotubes, and the temperature is reduced to $-30^{\circ} \mathrm{C}$ at a rate of $1 \mathrm{C} /$ hour, and then held at $-30^{\circ} \mathrm{C}$ for 24 hours.

- The tubes are placed in $\mathrm{LN}_{2}$ vapours for a long term storage

- Recovery/viability testing: Thawed material is rehydrated and grafted on rootstocks to grow a new tree (Forsline, et al. 1998).

Studies have shown that the materials which are cryopreserved retain their viability. In the below given Fig. 1 the germination percentage of kiwi variety Tomouri stored at different temperatures shows that germination was retained only when the pollen was stored in liquid nitrogen at $-196^{\circ} \mathrm{C}$.

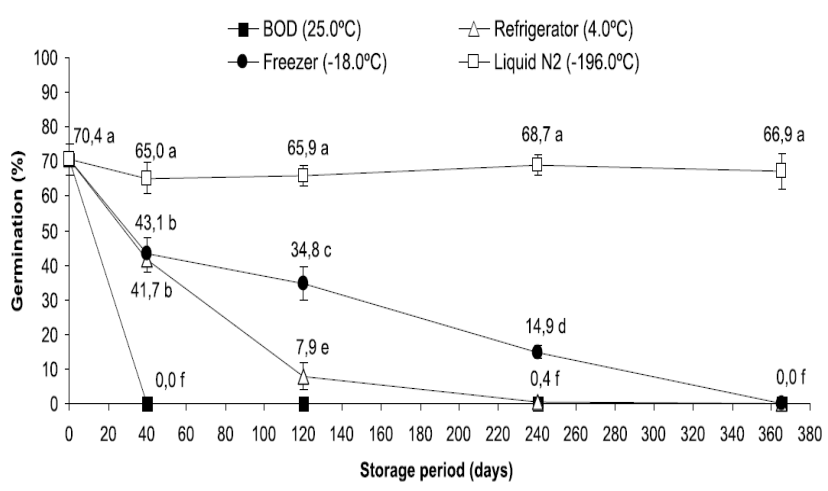

Fig. 1: In vitro germination of kiwi pollen grain of the variety Tomuri, preserved in different environments (Borghezen et al. 2011)

\section{Germplasm evaluation}

The main aim of evaluation is to identify gene sources for resistance to biotic and abiotic stresses, earliness, dwarfness, and quality characters and to know the significance of individual germplasm line. The germplasm evaluation is done by NBPGR.

\section{Registration of plant germplasm}

ICAR entrusted NBPGR as nodal agency for implementation of plant germplasm registration. 
Table 9: Horticultural crops registered at NBPGR

\begin{tabular}{|c|c|c|c|}
\hline $\begin{array}{c}\text { Botanical } \\
\text { name }\end{array}$ & Crop & $\begin{array}{l}\text { National identity } \\
\text { no. (INGR No.) }\end{array}$ & Institute \\
\hline $\begin{array}{l}\text { Citrullus } \\
\text { lanatus }\end{array}$ & $\begin{array}{l}\text { Water } \\
\text { melon }\end{array}$ & $\begin{array}{c}\text { IC296694 } \\
\text { (INGR98012) }\end{array}$ & $\begin{array}{c}\text { NRC on Arid } \\
\text { Horticulture, } \\
\text { Bikaner }\end{array}$ \\
\hline $\begin{array}{l}\text { Citrullus } \\
\text { lanatus }\end{array}$ & $\begin{array}{l}\text { Water } \\
\text { melon }\end{array}$ & $\begin{array}{l}\text { IC296816 } \\
\text { (INGR1037) }\end{array}$ & $\begin{array}{c}\text { ARS, } \\
\text { Durgapur, } \\
\text { Jaipur }\end{array}$ \\
\hline $\begin{array}{l}\text { Citrullus } \\
\text { lanatus }\end{array}$ & $\begin{array}{l}\text { Water } \\
\text { melon }\end{array}$ & $\begin{array}{l}\text { IC296817 } \\
\text { (INGR1038) }\end{array}$ & $\begin{array}{c}\text { ARS, } \\
\text { Durgapur, } \\
\text { Jaipur }\end{array}$ \\
\hline $\begin{array}{l}\text { Emblica } \\
\text { officinalis }\end{array}$ & Aonla & $\begin{array}{l}\text { IC296693 } \\
\text { (INGR98011) }\end{array}$ & $\begin{array}{l}\text { NBPGR, RS, } \\
\text { Bhowali }\end{array}$ \\
\hline $\begin{array}{l}\text { Mangifera } \\
\text { andamanica }\end{array}$ & Mango & $\begin{array}{l}\text { IC409079 } \\
\text { (INGR4122) }\end{array}$ & $\begin{array}{l}\text { CARI, Port } \\
\text { Blair }\end{array}$ \\
\hline $\begin{array}{l}\text { Mangifera } \\
\text { griffithi }\end{array}$ & Mango & $\begin{array}{l}\text { IC409066 } \\
\text { (INGR4060) }\end{array}$ & $\begin{array}{l}\text { CARI, Port } \\
\text { Blair }\end{array}$ \\
\hline $\begin{array}{l}\text { Mangifera } \\
\text { indica }\end{array}$ & Mango & $\begin{array}{l}\text { IC4296830 } \\
\text { (INGR3042) }\end{array}$ & $\begin{array}{c}\text { Individual, } \\
\text { Sultanpur, UP }\end{array}$ \\
\hline $\begin{array}{l}\text { Mangifera } \\
\text { indica }\end{array}$ & Mango & $\begin{array}{c}\text { IC427821 } \\
\text { (INGR4115) }\end{array}$ & $\begin{array}{c}\text { CISH, } \\
\text { Lucknow }\end{array}$ \\
\hline $\begin{array}{c}\text { Persia } \\
\text { bombycina }\end{array}$ & Avacado & $\begin{array}{l}\text { IC556923 } \\
\text { (INGR8055) }\end{array}$ & $\begin{array}{l}\text { CMER\&TI, } \\
\text { Jorhat }\end{array}$ \\
\hline Psidium spp. & Guava & $\begin{array}{c}\text { IC427822 } \\
\text { (INGR4116) }\end{array}$ & $\begin{array}{c}\text { CISH, } \\
\text { Lucknow }\end{array}$ \\
\hline $\begin{array}{l}\text { Zizyphus } \\
\text { maritiana }\end{array}$ & Ber & $\begin{array}{l}\text { IC296795 } \\
\text { (INGR1016) }\end{array}$ & $\begin{array}{l}\text { CCSHAU, } \\
\text { Hisar }\end{array}$ \\
\hline $\begin{array}{l}\text { Zizyphus } \\
\text { maritiana }\end{array}$ & Ber & $\begin{array}{c}\text { IC296798 } \\
\text { (INGR1017) }\end{array}$ & $\begin{array}{l}\text { CCSHAU, } \\
\text { Hisar }\end{array}$ \\
\hline $\begin{array}{l}\text { Zizyphus } \\
\text { maritiana }\end{array}$ & Ber & $\begin{array}{c}\text { IC296797 } \\
\text { (INGR1018) }\end{array}$ & $\begin{array}{c}\text { CCSHAU, } \\
\text { Hisar }\end{array}$ \\
\hline
\end{tabular}

(Singh, 2010).

\section{Germplasm utilization}

Germplasm is utilized in two ways:

- Cultivated germplasm: Used as a variety or as a parent in hybridization.

- Wild germplasm: Transfer of resistant genes to biotic and abiotic stresses and quality characters.

\section{Organizations associated with plant genetic resources}

(a) IBPGR: Established in 1974

(b) IPGRI: Established by CGIAR (Consultative Group on International Agricultural Research) in 1994, situated in Rome, Italy at Food and Agriculture Organization of United Nations. It conducts research and promotes
International network of Plant Genetic Resources activities.

(c) NBPGR: NBPGR was established by the Indian Council of Agricultural Research (ICAR) in 1976 with its main campus at New Delhi. Acts as nodal institute at national level for acquisition and management of indigenous and exotic plant genetic resources (PGR) for food and agriculture and carry out related research.

\section{Important developments in plant genetic resources}

- Convention of Biological Diversity (CBD): 1993

- The International Treaty on Plant Genetic Resources for Food and Agriculture (ITPGRFA): 2001

- The Protection of Plant Varieties and Farmers Rights Act (PPVFRA): 2001

- The Biological Diversity Act (BDA) : 2002

\section{CONCLUSION}

In the situation of climate change and depletion of natural resources, the challenges are more to feed growing population, so many efforts are required for exploring the unexplored areas for collection of horticultural biodiversity wealth for conservation and further utilization for the benefit of mankind. In the quest to meet the emerging challenges, the gains with respect to genetic resources have to be sustained and further collection of new genes are required to be looked and utilized for gains where the strong base of horticultural plant biodiversity have to be in driving seat for bringing gene revolution.

\section{REFERENCES}

Anonymous. 2013. Annual Report of the National Bureau of Plant Genetic Resources 2012-2013, NBPGR, Pusa Campus, New Delhi, India, 186+vi p.

Borghezan, M., Clauman, A. D., Steinmacher, D.A., Guerra, M. P. and Orth, A.I. 2011. In vitro viability and preservation of pollen grain of kiwi (Actinidia chinensis var. deliciosa (A. Chev.) A. Chev). Crop Breeding and Applied Biotechnology 11: 338-344.

Chandel, K.P. S. and Pandey, R. 1991. Plant Genetic Resources Conservation: Recent Approaches. In: Plant genetic resources conservation and management concepts and approaches. [Ed. Paroda, R.S.], pp. 461-472. 
Chaudhary, R. 2000. Cryopreservation of seeds, embryos, embryonic axes and pollen at National Cryobank of NBPGR. In: Cryopreservation of tropical plant germplasm, Current Research Progress and Aplication, JIRCAS/IPGRI, Rome, Italy [Ed. Engelmann, F. and Takai, H.].pp. 457-459.

FAO. 2010. Access to plant genetic resources, the sharing of benefits, arising out of their utilization and the realization of farmer's rights. Chapter7: State of the World's plant genetic resources for food and agriculture: The second Report. FAO, Rome.

Fazio, G. Forsline, P., Aldwinckle, H. and Pons, L. 2008. The Apple Collection in Geneva, NY: A Resource for The Apple Industry Today and for Generations to Come. New York Fruit Quarterly, 16(1): 1-4.

Forsline, P.L., Towill, L.E., Waddell, J.W., Stushnoff, C., Lamboy, W.F. and Mcferson, J.R. 1998. Recovery and longevity of cryopreserved dormant apple buds. Journal of American Society of Horticulture Sciences, 123(3): 365-370.

Gupta, S. 2010. Management of Temperate fruit genetic resources in India. Acta Horticulturae: 71-80.

http:// www.wikipedia.com

http://www.conservation.org

http://www.cith.org.in

Jeffreys, A.J., Wilson, V. and Thein, S.L. 1985. Individual specific fingerprints of Human DNA. Nature, 316: 76-79.
Nabhan, G.P. 2010. How Climate Change Is Already Affecting the Conservation of Fruit Diversity. In: Genetic Resources: New Tools for the Conservation and Management of Genetic Resources in Horticulture. IHC, Lisbon, pp. 1-6

NBPGR, 2011; http://www.nbpgr.ernet.in

Rana, R.S. 2012. Accessing Plant Genetic Resources and Sharing the Benefits: Experiences in India. Indian Journal of Plant Genetic Resources, 25(1): 31-51.

Reed, B.M. 1992. Cold storage of strawberries in vitro: a comparison of three storage systems. Fruit Var. J., 46: 98-102.

Singh, H.P. 2010. Managing genetic resources of horticultural crops. Indian Horticulture, 55(3): 3-16.

Vavilov, N.I. 1951. The origin, variation, immunity and breeding of cultivated plants. Soil Science, 72(6): 482.

Wani, N. 2011. Genetic diversity estimates in some Walnut (Juglans regia L.) accessions using molecular markers and phenotypic data. Dissertation submitted to Division of Fruit Science, Sher-e-Kashmir University of Agricultural Sciences and Technology, Kashmir, pp. 1-96.

Wilkins, C.P., Newbury, H.J. and Dodds, J.H. 1988. Tissue Culture conservation of fruit trees. FAO/IBPGR Plant Genetic Resource Newsletter, 73/74: 9-20.

Zhang Qiong, Jing Li, Yongbo Zhao, Schuyler S. Korban \& Yuepeng Han 2012. Evaluation of Genetic Diversity in Chinese Wild Apple Species Along with Apple Cultivars Using SSR Markers. Plant Mol. Biol. Rep., 30: 539-546. 